\title{
Jurisdiction agreements:
}

\section{exclusive, optional and asymmetrical}

\author{
Mary Keyes $^{a}$ and Brooke Adele Marshall ${ }^{b}$
}

The paradigm of the jurisdiction agreement designates a single, exclusive forum, allowing each party to determine, in advance of a dispute, the forum for litigation. The principles governing the enforcement of jurisdiction agreements are largely designed for this model. Some parties draft agreements that differ from this model, including agreements that purport to nominate multiple courts with "exclusive" jurisdiction, and unilateral optional agreements giving one party an option to select the forum after a dispute arises. These features raise the question of whether principles developed for the exclusive model regulate jurisdiction agreements that depart from it. This article explores the approach to exclusivity under the Hague Choice of Court Convention, the Brussels I Recast, and at common law. We demonstrate that non-uniquely "exclusive" and unilateral optional jurisdiction agreements are uncomfortably accommodated within and inconsistently treated by these regimes, comparing, particularly, the acceptance of unilateral optional agreements in England with their rejection in France.

Keywords: Private international law; jurisdiction agreements; choice of court; common law; Hague Choice of Court Convention; Brussels I Recast Regulation; English and French case law; optional; unilateral; asymmetric; exclusive; nonexclusive

\footnotetext{
${ }^{\text {a }}$ Professor of Law, Griffith University, Brisbane, Australia. Email: m.keyes@griffith.edu.au. ${ }^{\mathrm{b}}$ Senior Research Fellow, Max Planck Institute for Comparative and International Private Law, Hamburg, Germany. We thank the anonymous referees for their detailed comments and suggestions.
} 


\section{A. Introduction}

Most legal systems uphold expressed agreements as to forum between commercial parties in cross-border transactions. ${ }^{1}$ The principles governing the enforcement of express choices of forum are, largely, designed for exclusive jurisdiction agreements that designate a single forum to the exclusion of all other fora and apply to the parties without differentiation. Although many jurisdiction agreements are of this type, courts are increasingly called upon to interpret and enforce jurisdiction agreements that do not conform to this model. Perhaps the most controversial are those which give one party a choice about the forum in which proceedings may be brought. These are known as unilateral optional jurisdiction clauses and are commonplace, particularly in international financial agreements. This type of clause was at issue in the controversial decision of the highest court in France (Cour de cassation) in Rothschild. $^{2}$

Common law courts treat unilateral optional agreements as legitimate and enforceable, ${ }^{3}$ whereas superior courts of several other countries have recently refused

\footnotetext{
${ }^{1}$ Subject matter jurisdiction is not contractible. In this article, our references to jurisdiction refer only to personal jurisdiction unless otherwise expressly stated.

${ }^{2}$ Cass civ, 1ère, 26.09.2012, Madame X v Banque Privée Edmond de Rothschild, No 11-26.022 (Rothschild). See P Ancel and G Cuniberti, "Cour de cassation française (1re ch. civ.), 26 septembre 2012, Observations" (2013) 25 Journal des tribunaux, Luxembourg 7; A Briggs, "One-sided Jurisdiction Clauses: French Folly and Russian Menace" [2013] Lloyd's Maritime and Commercial Law Quarterly 137; R Fentiman, "Unilateral Jurisdiction Agreements in Europe" (2013) Cambridge Law Journal 24; R Freitag, "Halbseitig ausschließliche Gerichtsstandsvereinbarungen unter der Brüssel I-VO", in P Mankowski and W Wurmnest (eds) Festschrift für Ulrich Magnus zum 70 Geburtstag (Sellier, 2014) 419. One author describes the decision of the Cour de cassation in Rothschild as "more than peculiar, and to a certain extent com[ing] close to being absurd": D Draguiev, "Unilateral Jurisdiction Clauses: The Case for Invalidity, Severability or Enforceability" (2014) Journal of International Arbitration 19, 37.

${ }^{3}$ Eg Armadora Occidental SA v Horace Mann Insurance Co [1977] 1 WLR 520; Dubai Electricity Co $v$ Islamic Republic of Iran (The "Iran Vojdan") [1984] 2 Lloyd's Rep 380; Ocarina Marine Ltd v Marcard Stein \& Co [1994] 2 Lloyd's Rep 524; Mauritius Commercial Bank Ltd v Hestia Holdings Ltd [2013] EWHC 1328 (Comm); [2013] 2 All ER 898.
} 
to enforce them. ${ }^{4}$ The Cour de cassation in Rothschild and again in ICH v Crédit

suisse $^{5}$ held a unilateral optional agreement to be unenforceable.

A more unusual but not uncontroversial type of agreement nominates more than one court as having "exclusive" jurisdiction. We refer to these as non-uniquely exclusive agreements. These agreements nominate one court with "exclusive" jurisdiction for each party, or two or more courts with "exclusive" jurisdiction for both parties. Little attention has been directed to the enforceability and effects of non-uniquely exclusive agreements.

With the European Union's Brussels I Recast Regulation (Recast) ${ }^{6}$ and the Hague Choice of Court Convention (Hague Convention) ${ }^{7}$ having entered into force in January 2015 and October 2015, respectively, it is timely to consider whether existing principles are capable of regulating non-uniquely exclusive and unilateral optional jurisdiction agreements. This article contributes to the literature on this point by

\footnotetext{
${ }^{4}$ Russkaya Telefonnaya Kompaniya (RTK) v Sony Ericsson Mobile Communications Rus Vestnik Vysshego Arbitrazhnogo Suda RF [Vestn. VAS] [The Highest Arbitration Court of the Russian Federation Reporter] 2012, No. 10; Bulgarian Supreme Court of Cassation, Judgment No. 71 in commercial case No. 1193/2010, Bulgarian Supreme Court of Cassation (2 September 2011). The Bulgarian Supreme Court judgment is summarised by Dr Dafina Sarbinova, Conflict of Laws.net http://conflictoflaws.net/2012/bulgarian-court-strikes-down-one-way-jurisdiction-clause/ accessed on 10 May 2015.

${ }^{5}$ Cass civ, 1ère, 25.03.2015, ICH v Crédit suisse, No 13-27264.

${ }^{6}$ Regulation (EU) No 1215/2012 of the European Parliament and of the Council of 12 December 2012 on Jurisdiction and the Recognition and Enforcement of Judgments in Civil and Commercial Matters [2012] OJ L351/1. The Recast provisions relevant to commercial jurisdiction agreements differ materially to the related provisions of its predecessor: Regulation (EC) 44/2001 of 22 December 2000 on Jurisdiction and the Recognition and Enforcement of Judgments in Civil and Commercial Matters [2001] OJ L12/1 (Regulation). The Regulation took effect for all the then Member States of the European Union on 1 March 2002 except Denmark, for which it took effect on 1 July 2007. It replaced the Convention on Jurisdiction and the Enforcement of Judgments in Civil and Commercial Matters of 27 September 1968 [1998] OJ C27/01 (Brussels Convention).

${ }^{7}$ Hague Convention of 30 June 2005 on Choice of Court Agreements. The Hague Convention entered into force on 1 October 2015 following the deposit of the instrument of approval by the President of the Council of the European Union in July 2015. The European Union became the second Contracting Party to the convention, after Mexico, thus triggering its entry into force: Hague Convention, Art 31(1). The European Union's ratification is likely to prompt other states to ratify the Hague Convention because non-Member State courts do not receive the same protection as Member State courts under the Recast when designated in an exclusive choice of court agreement. See P Beaumont, "The Revived Judgments Project in The Hague" (2014) Nederlands Internationaal Privaatrecht 532, 539.
} 
analysing the differing concepts and effects of exclusivity, and surveying and comparing the treatment of jurisdiction agreements in commercial cases, under the Hague Convention, the Recast ${ }^{8}$ and at common law, referring in particular to English national law. ${ }^{9}$ While there has been a general convergence in the treatment of jurisdiction agreements, as we show, important points of difference remain.

This article comprises four more sections. In section B, we introduce the policies and assumptions that inform the principles governing the treatment of jurisdiction agreements, and describe those principles generally, under the Hague Convention, the Recast, and at common law. In section $\mathrm{C}$, we analyse the concept of exclusivity, considering the strong distinction between exclusive and non-exclusive jurisdiction agreements, and the phenomenon of non-unique exclusive agreements; again, comparing the treatment of each type of agreement under the Hague Convention, in the European Union and at common law. In section D, we analyse unilateral optional clauses which have both exclusive and non-exclusive features, especially focusing on the Rothschild case and ICH v Crédit suisse. Section E concludes with some notes of caution about the use of non-unique exclusive and unilateral optional jurisdiction agreements.

\footnotetext{
${ }^{8}$ We do not consider the application of the Recast's provisions where the courts nominated in a jurisdiction agreement are not in a jurisdiction that is a Member State of the European Union. See generally, P A Nielson, “The New Brussels I Regulation” (2013) Common Market Law Review 503, 512-518.

${ }^{9}$ Most jurisdictional disputes in the English courts are subject to the Regulation, and following its entry into effect on 10 January 2015, almost all such disputes will be determined according to the provisions of the Brussels I Recast. This substantially reduces the scope for application of the common law although previous decisions of English courts are likely to retain persuasive value for common law courts outside of Europe.
} 


\section{B. The legal treatment of jurisdiction agreements}

Parties to cross-border commercial transactions are naturally exposed to the risk of disputes and consequently to the potential of litigation in multiple legal systems. An important underlying policy of the rules of jurisdiction is to minimise this potential and the attendant risk of inconsistent judgments. In cases involving a natural plaintiff and defendant, the basic rules of jurisdictional competency achieve this by requiring a unique connection between the litigation and the forum. For example, under the Recast, jurisdiction is generally based on the defendant's domicile. ${ }^{10}$ The fundamental rules of competence have been supplemented by additional rules which do not require unique connections. The expansion in the rules of competence increases the potential for parallel proceedings and proceedings being commenced in an unsuitable forum. In turn, the default rules used to resolve parallel proceedings and to stay proceedings that have been brought in an unsuitable forum both have flaws. The lis pendens rule is unsubtle and rigid, and creates an incentive for both parties hastily to commence proceedings. The principle of forum non conveniens on the other hand may be criticised as being too flexible. Both the lis pendens rule and the forum non conveniens principle impede settlement and increase the public and private costs of litigation.

Agreements are seen as the best solution to these problems, which are inherent in jurisdictional principles, and to the risk of litigation in multiple legal systems. ${ }^{11}$

\footnotetext{
${ }^{10}$ Recast, Art 4. Where the defendant also has claims, the connection loses its uniqueness, and a mechanism is needed to resolve the risk of parallel proceedings being brought in the respective domiciles of the plaintiff and defendant.

${ }^{11}$ In Fiona Trust v Privalov [2007] UKHL 40, [2008] 1 Lloyd's Rep 254, [25], Lord Hope stated that the purpose of arbitration clauses "is to avoid the expense and delay of having to argue about these matters later". See likewise Carnival Cruise Lines, Inc v Shute 499 US 585, 594 (1991). This article is only concerned with express submissions to the jurisdiction, not implied agreements or submission
} 
They enable parties to determine where they are entitled to bring, and may be required to defend, proceedings. ${ }^{12}$ If routinely enforced, jurisdiction agreements facilitate the relatively certain, predictable and efficient resolution of jurisdictional disputes, and minimise the likelihood of multiple proceedings.

The law relating to the enforcement of agreements in private international litigation has developed rapidly. ${ }^{13}$ This development is based on the assumptions that a jurisdiction agreement will allow each party to ascertain in advance the forum in which it may be required to participate in litigation, and will affect the parties equally. It is also generally assumed that every agreement will designate a single jurisdiction and that every agreement can be characterised as either exclusive or non-exclusive. ${ }^{14}$ This characterisation is significant because exclusive and non-exclusive jurisdiction agreements differ fundamentally as to the positive and negative effects that they produce. ${ }^{15}$

Characterisation of a jurisdiction agreement as exclusive or non-exclusive will become all the more significant in the European Union now that the Hague Convention has come into effect, because it determines which regime (Recast or Hague Convention) a Member State court must apply. The purpose of the Hague Convention is to regularise the treatment of choice of court agreements

implied from conduct (tacit prorogation), such as where one party has entered an unconditional appearance.

${ }^{12}$ See Case C-269/95, Benincasa v Dentalkit Srl [1997] ECR I-3788, 3798, [29].

${ }^{13}$ M Keyes, Party Autonomy in Private International Law (Oxford University Press, forthcoming).

${ }^{14}$ Joseph refers to this distinction as being of "central importance" to the operation of the Hague Convention and the Regulation, and notes its likely significance at common law both for the enforcement of a jurisdiction clause and any damages claim related to the clause: D Joseph, Jurisdiction and Arbitration Agreements and their Enforcement (Sweet \& Maxwell, 2nd edn, 2010) para 4.03

${ }^{15}$ Whether this "binary distinction" remains the best organising principle for jurisdiction agreements has been questioned: A Briggs, "The Subtle Variety of Jurisdiction Agreements" [2012] Lloyd's Maritime and Commercial Law Quarterly 364, 376. 
internationally. It only applies to exclusive agreements. ${ }^{16}$ It was inspired by and seeks to emulate the success of the United Nations Convention on the Recognition and Enforcement of Foreign Arbitral Awards 1958 (the New York Convention). Following the approach of the New York Convention, the Hague Convention requires strict enforcement of exclusive jurisdiction agreements.

The provisions of the successive Brussels instruments relevant to jurisdiction agreements are not identical. In this article, we focus on the provisions of the Recast, which applies to proceedings instituted in the European Union from 10 January 2015. The Hague Convention displaces the Recast for unique exclusive agreements ${ }^{17}$ designating the courts of a Member State of the European Union if either party is resident in a Contracting State to the Hague Convention that is not a Member State of the EU. ${ }^{18}$ In the following discussion of the Recast, we note important similarities to, as well as changes from, the relevant provisions of the Regulation and the Brussels Convention dealing with jurisdiction agreements. ${ }^{19}$ Like the Regulation and the

\footnotetext{
${ }^{16}$ See generally, P Beaumont, "Hague Choice of Court Agreements Convention 2005: Background, Negotiations, Analysis and Current Status" (2009) Journal of Private International Law 125, 134. ${ }^{17}$ See infra, section C1(b).

${ }^{18}$ Hague Convention, Art 26(6)(a). See also European Commission, Proposal for a Council Decision on the approval, on behalf of the European Union, of the Hague Convention of 30 June 2005 on Choice of Court Agreements of 30 January 2014 COM(2014) 46 final. ). A European Union Member State court whose jurisdiction is prorogated by the clause is obliged to apply the Hague Convention to an agreement concluded after 1 October 2015, Art 16(1). A European Union Member State court whose jurisdiction is derogated by the clause is obliged to apply the Hague Convention if two conditions are met: if the agreement was concluded after the convention entered into force for the State of the chosen court and if the proceedings were instituted before the EU Member State court after 1 October 2015 (the date of entry into force of the convention for the State of the court seised), see Art 16(1) and (2) as explained by T Hartley and M Dogauchi, Explanatory Report on the Convention of 30 June 2005 on Choice of Court Agreements (Hague Conference on Private International Law, 2005) paras 218-220, see http://www.hcch.net/index_en.php?act=publications.details\&pid=3959\&dtid=3 accessed 5 October 2015. For criticism of Art 16, see Catherine Kessedjian, « Convention de la Haye du 30 juin 2005 sur l'élection de for » (2006) Journal du droit international 813, 819-820.

${ }^{19}$ In part D, we also refer to two cases involving the application of the Lugano Convention. We refer to ICH v Crédit suisse, supra $\mathrm{n} 5$, which concerned Art 23 of the Convention on Jurisdiction and the Recognition and Enforcement of Judgments in Civil and Commercial Matters of 21 December 2007, [2009] OJ L147/5 (2007 Lugano Convention) which is identical to Art 23 of the Regulation, and to Lornamead Acquisitions Ltd v Kaupthing Bank HF [2011] EWHC 2611 (Comm); [2013] BCLC 73 which involved the application of Art 17 of the earlier version of the Lugano Convention (Convention on Jurisdiction and the Recognition and Enforcement of Judgments in Civil and Commercial Matters of
} 
Brussels Convention, the Recast focuses on exclusive agreements, and uses lis pendens as the basic rule for resolving jurisdictional overlaps. Unlike the Regulation and the Brussels Convention, the Recast specifically excludes exclusive jurisdiction agreements from the general lis pendens rule. Neither the Regulation nor the Recast contains a provision equivalent to Article 17(5) of the Brussels Convention, the ongoing legacy of which seems to have been to inspire the use of unilateral jurisdiction agreements but not necessarily their enforcement.

While the common law gives primacy to agreements, jurisdiction agreements are only enforced by staying proceedings in the courts' discretion. ${ }^{20}$ In exercising that discretion, the courts are concerned to prevent multiple proceedings, which has become the strongest ground for resisting enforcement of jurisdictional agreements.

16 September 1988 [1988] OJ L319/9 (1988 Lugano Convention) which is identical to Art 17 of the Brussels Convention. Iceland, Switzerland, Norway, the EU and Denmark are parties to the Lugano Convention.

${ }^{20}$ The other means of enforcing jurisdiction agreements in the common law are restraining foreign proceedings by antisuit injunctions, and granting damages for breach of contract. The grant of an antisuit injunction is always discretionary, but the award of damages for breach is not. 


\section{Exclusivity}

The Hague Convention, Brussels instruments ${ }^{21}$ and, albeit less explicitly, the common law, each operates on the assumption that the parties intended jurisdiction agreements to be exclusive, on the bases that the parties prefer certainty to flexibility, that certainty is considerably enhanced by the choice of a single jurisdiction, and that the parties do not intend to litigate the same dispute in multiple jurisdictions. The selection of a single forum should limit the scope for and of jurisdictional disputes, facilitate settlement, and minimise the public and private costs of litigation. In this section, we consider the distinctions between exclusive, non-unique exclusive and non-exclusive agreements, and compare the treatment of each type under each regime.

\section{Exclusive jurisdiction agreements}

Under the Hague Convention, whether an agreement is exclusive is a matter resolved entirely by the provisions of the Convention. ${ }^{22}$ The Hague Convention deems a choice of court agreement to be exclusive "unless the parties have expressly provided otherwise". ${ }^{23}$ In order to be exclusive, the Hague Convention requires the agreement to select the courts of only one jurisdiction. ${ }^{24}$ Any agreement which does not exclude the jurisdiction of the courts of all but those of a single chosen jurisdiction is regarded as non-exclusive, notwithstanding that the parties may have characterised the choice

\footnotetext{
${ }^{21}$ A Briggs, Private International Law in English Courts (Oxford University Press, 2014), para 4.185. Below, we discuss the possibility of non-unique jurisdiction agreements: section $\mathrm{C} 1$.

${ }^{22} \mathrm{R}$ Fentiman, International Commercial Litigation (Oxford University Press, $2^{\text {nd }}$ edn, 2015), para

2.145; R Brand and P Herrup, The 2005 Hague Convention on Choice of Court Agreements: Commentary and Materials (Cambridge University Press, 2008), 17, $42-43$.

${ }^{23} \operatorname{Art~3(b).~}$

${ }^{24}$ Art 3(a).
} 
of a number of different jurisdictions as "exclusive", ${ }^{25}$ and is therefore outside the Convention.

The Recast is similar to the Hague Convention, deeming a choice of court agreement to be exclusive "unless the parties have agreed otherwise". ${ }^{26}$ The Recast does not define exclusivity, but the effect of a jurisdiction agreement is an autonomous matter. ${ }^{27}$ Although the Recast, like the Regulation and Convention, refers to the courts of a single Member State, the Court of Justice of the European Union (CJEU) in Meeth $v$ Glacetal ruled that a jurisdiction agreement was exclusive under the Brussels Convention, if it excluded the jurisdiction of all other competent Member State courts for each party. ${ }^{28}$ There is nothing to suggest that exclusivity should be conceptualised differently under the Recast. Accordingly, any agreement that does not exclude the jurisdiction of all but the single chosen jurisdiction for each party should be regarded as non-exclusive under the Recast notwithstanding that the parties may have characterised it as "exclusive". ${ }^{29}$

\footnotetext{
${ }^{25}$ T Hartley and M Dogauchi, supra n 18, paras 40, 47-48 and 104.

${ }^{26}$ Art 25.

${ }^{27}$ The effect of a jurisdiction agreement should be distinguished from its scope which the CJEU has held can be interpreted by referring to the law governing the jurisdiction agreement: Powell Duffryn plc $v$ Wolfgang Petereit [1992] ECR I-1769, 1778, [37]. Whether an agreement is exclusive or nonexclusive is properly a question of effect, not scope.

${ }^{28}$ The CJEU's ruling in Case 23/78, Meeth v Glacetal Sarl [1978] ECR 2133 expanded its previous jurisprudence. In Case 24/76, Estasis Salotti di Colzani Aimo e Gianmario Colzani snc v Rüwa Polstereimaschinen GmbH [1976] ECR 1831, 1841, [7] and Case 25/76, Segoura v Bonakdarian [1976] ECR 1852, 1860, [6] the court observed that "the effect of the conferment of jurisdiction by consent ... is to exclude both the jurisdiction determined by the general principle laid down in Article 2 and the special jurisdictions provided for in Articles 5 and 6 of the Convention". In Meeth, the court ruled that a clause which had this effect for each party was effective. The court relevantly stated at 2142 that "Although such an agreement coincides with the scope of article 2 it is nevertheless effective in that it excludes, in relations between the parties, other optional attributions of jurisdiction, such as those detailed in articles 5 and 6 of the convention". Because Art 17 of the Convention applied only to exclusive jurisdiction clauses, (subject to one exception which we discuss below), Meeth can be understood as defining an exclusive clause as one which excludes the default rules of jurisdiction for each party. See infra text to nn 103-109.

${ }^{29} \mathrm{Cf}$ U Magnus, in U Magnus and P Mankowski (eds), Brussels I Regulation (Sellier, $2^{\text {nd }}$ edn, 2012), Art 23 para 147; and Fentiman, supra n 22, para 2.52 who suggest that an agreement is exclusive under the Regulation and Recast respectively in the absence of the word "exclusive", unless it expressly
} 
At common law, whether an agreement is exclusive is a question of construction to be determined by the governing law. ${ }^{30}$ The question is whether the clause obliges the parties to litigate in the chosen court. The use of the word "exclusive" is relevant but not decisive in determining whether a clause should be given exclusive effect. ${ }^{31}$ While the common law does not strictly presume exclusivity, there is a tendency to conclude that jurisdiction agreements are exclusive ${ }^{32}$ which is assumed to be the intention of rational commercial parties. ${ }^{33}$

(a) The effects of an exclusive agreement

\footnotetext{
states that it is non-exclusive. Fentiman implies that if the parties describe the jurisdiction of a court as "exclusive", then a court should treat it as exclusive, albeit for some purposes and not for others: Ibid, para 2.145 .

${ }^{30}$ Either the governing law of the contract as a whole, or the governing law of the jurisdiction agreement specifically.

${ }^{31}$ Continental Bank NA v Aeakos Compania Naviera SA [1994] 1 WLR 588, 594. See also R Mortensen, "The Hague and the Ditch: The Trans-Tasman Judicial Area and the Choice of Court Convention" (2009) Journal of Private International Law 213, 230-231.

32 J Fawcett, "Non-exclusive jurisdiction agreements in private international law" [2001] Lloyd's Maritime and Commercial Law Quarterly 234, 240 (suggesting that the English courts operated a "covert principle in favour of exclusivity"). See also R Garnett, "The Enforcement of Jurisdiction Clauses in Australia" (1998) University of New South Wales Law Journal 1, 7 and R Garnett, "The Hague Choice of Court Convention: Magnum Opus or Much Ado about Nothing?" (2009) Journal of Private International Law 161, 164. The English Court of Appeal's treatment of a non-exclusive agreement in Sabah Shipyard (Pakistan) Ltd v Islamic Republic of Pakistan has reduced the importance of the distinction between exclusive and non-exclusive jurisdiction agreements: [2003] 2 Lloyd's Rep 571. See infra $\mathrm{n} 93$ and accompanying text.

${ }^{33}$ See, eg Continental Bank, supra n 31, 593; FAI General Insurance Co Ltd v Ocean Marine Mutual Protection and Indemnity Association (1997) 41 NSWLR 117, 127; BNP Paribas SA v Anchorage Capital Europe LL P [2013] EWHC 3073 (Comm), [91].
} 
An exclusive agreement has both positive and negative effects. It positively obliges the parties, if they do litigate, to litigate in the nominated court. Most legal systems require their courts to accept jurisdiction based on the parties' agreement. Exclusive agreements also have the negative effect, usually only by implication, of excluding the options that the parties would otherwise have to litigate in other courts. Courts other than those which are chosen are, accordingly, obliged to stay proceedings brought in breach of an exclusive jurisdiction agreement.

(i) The positive effects of an exclusive agreement. Under the Hague Convention, ${ }^{34}$ the Recast, ${ }^{35}$ and at common law, ${ }^{36}$ the parties may invoke the court's jurisdiction relying on their agreement, although they cannot thereby overcome subject-matter jurisdictional limitations. ${ }^{37}$

The Hague Convention gives exclusive prorogation agreements a high level of protection in that a court of a Contracting State that has jurisdiction under an exclusive choice of court agreement "shall not decline to exercise jurisdiction on the ground that the dispute should be decided in a court of another State". ${ }^{38}$

\footnotetext{
${ }^{34}$ Hague Convention, Art 5(1).

35 Recast, Art 25.

${ }^{36}$ Sohio Supply Co v Gatoil (USA) Inc [1989] 1 Lloyd's Rep 588.

${ }^{37}$ Various subject matters are excluded from the scope of the Hague Convention, under Art 2(2). The rules of exclusive subject matter jurisdiction are contained in Art 24 of the Recast. They concern proceedings inter alia relating to rights in rem in or tenancies of immovable property, the validity of intellectual property rights and the enforcement of judgments. Where a court of a Member State is seised of a claim that is principally concerned with a matter over which the courts of another Member State have exclusive jurisdiction, it shall declare of its own motion that it has no jurisdiction. In such a case, a Member State court, designated in an agreement pursuant to which jurisdiction under Art 25 has been invoked, has no jurisdiction: Recast, Art 25(4).

There are a number of limitations to the subject-matter jurisdiction of courts recognised at common law. For example, the court lacks jurisdiction to deal with issues of title to and possession of foreign land: British South Africa Co v Companhia de Moçambique [1893] AC 602.

${ }^{38}$ Hague Convention, Art 5(2).
} 
An exclusive clause has an obligatory, positive effect under the Brussels instruments. ${ }^{39}$ Under the Recast, a chosen court has no discretion to decline jurisdiction which is based on an exclusive agreement. ${ }^{40}$ In this regard the Recast differs from the Regulation, in respect of which the CJEU in Gasser v MISAT ruled that the general lis pendens rule applied even if the parties had agreed to litigate exclusively in a court other than that first seised of jurisdiction. ${ }^{41}$ Commentators strongly criticised the decision in Gasser because its interpretation undermined the certainty that exclusive jurisdiction agreements are designed to ensure and encouraged the use of torpedo dilatory tactics. ${ }^{42}$ The Recast responds to these criticisms by excepting unique exclusive jurisdiction clauses from the lis pendens rule. $^{43}$

Common law courts always retain the discretion to decline to exercise jurisdiction, even if the parties have contractually submitted to their jurisdiction. An

\footnotetext{
${ }^{39}$ The obligatory effect of a clause conferring unique exclusive jurisdiction under Art 25 of the Recast is beyond doubt, although this effect is implied rather than expressed. Cf the obligatory effect of exclusive subject-matter jurisdiction under Art 24 which is expressly dealt with in Art 27 of the Recast. Whether a non-unique exclusive clause has an obligatory effect is uncertain. As we explain below, this turns on whether Art 31(1) properly applies to non-unique exclusive jurisdiction agreements. See discussion infra text to nn 75-85.

${ }^{40}$ Briggs, supra n 21, para 4.40.

${ }^{41}$ Case C-116/02, Erich Gasser GmbH v MISAT Srl [2003] ECR I-14721, 14741, [46]-[49]; Case C438/12, Irmengard Weber v Mechthilde Weber EU:C:2014:212 , [52]; Cf Continental Bank, supra $\mathrm{n}$ 29,596 .

${ }^{42}$ One party would boycott the effect of an exclusive jurisdiction clause by pre-emptively seising a Member State court that had no basis on which to assume jurisdiction, and in which proceedings to make a ruling to that effect would be excessively lengthy. See generally, J Mance, "Exclusive Jurisdiction Agreements and European Ideals" (2004) The Law Quarterly Review 357; D Bureau and H Muir Watt, Droit international privé (Presses universitaires de France, $3^{\text {rd }}$ edn, 2014), 378-379; M Niboyet and G de Geouffre de la Pradelle, Droit international privé (Lextenso editions, $4^{\text {th }}$ edn, 2013), 321-322.

${ }^{43}$ Recast, Art 31(2). Heinze observes that the exception will "apply for most jurisdiction agreements" because exclusivity is presumed: C Heinze, "Choice of Court Agreements, Coordination of Proceedings and Provisional Measures in the Reform of the Brussels I Regulation" (2011) Rabels Zeitschrift 581, 589, n 30.
} 
exclusive prorogation clause ${ }^{44}$ will be enforced unless the defendant can establish strong reasons for non-enforcement. ${ }^{45}$ The clearest example of strong reasons is where related proceedings, involving parties or issues outside the agreement's scope, have already been instituted in a foreign court that has jurisdiction over all the parties and matters in dispute. ${ }^{46}$ In that case, "the interests of justice are best served by the submission of the whole dispute to a single tribunal which is best fitted to make a reliable, comprehensive judgment on all the matters in issue". ${ }^{47}$ In other words, the public policy in favour of singular proceedings, to minimise the risk of inconsistent judgments, may be given priority over an exclusive jurisdiction agreement.

(ii) The negative effect of an exclusive agreement. In addition to its positive effect in prorogating the jurisdiction of the chosen court, a unique exclusive jurisdiction agreement has the negative effect of excluding the options the parties would otherwise have had to litigate in any competent court other than the chosen court. ${ }^{48}$ The Hague Convention takes a strict approach to the enforcement of exclusive jurisdiction agreements by non-chosen courts. ${ }^{49}$ It requires the courts of Contracting States to "suspend or dismiss proceedings to which an exclusive choice of court

\footnotetext{
${ }^{44}$ This may be done by refusing to stay forum proceedings, by granting an antisuit injunction to prevent commencement or continuation of proceedings in a foreign court, and by awarding damages for breach of contract.

${ }^{45}$ Donohue v Armco Inc [2002] 1 All ER 749, 759.

${ }^{46}$ Ibid; Bouygues Offshore SA v Caspian Shipping Co [1998] 2 Lloyd's Rep 461.

${ }^{47}$ Donohue v Armco, supra $\mathrm{n}$ 45, 764 (emphasis added). In this case, counsel for the party seeking a stay of English proceedings conceded that the commencement of foreign proceedings constituted a breach of contract which could found a claim for damages: Ibid, 765. This concession appears to have influenced the willingness of the court to stay the English proceedings. In England and Australia, it is now accepted that breach of a jurisdiction clause gives rise to a right to damages: Starlight Shipping Co v Allianz Marine \& Aviation Versicherungs AG [2014] EWCA 1010; Compagnie des Messageries Maritime v Wilson (1954) 94 CLR 577, 587; Commonwealth Bank v White (No 2 of 2004) [2004] VSC 268, [5]; R Garnett, "Jurisdiction Clauses Since Akai" (2013) Australian Law Journal 134, 148-149.

${ }^{48}$ See Ust-Kamenogorsk Hydropower Plant JSC v AES Ust-Kamenogorsk Hydropower Plant LLP [2013] UKSC 35, [21].

${ }^{49}$ As noted above, the Hague Convention applies only to exclusive choice of court agreements.
} 
agreement applies" with very limited exceptions. ${ }^{50}$ As we explained above, the Recast protects explicitly the derogative effect of an exclusive choice of another Member State court by excepting it from the normal lis pendens rule. ${ }^{51}$ At common law, exclusive jurisdiction agreements are not enforceable per se, ${ }^{52}$ but a court will stay proceedings in favour of a foreign legal system designated in an exclusive derogation agreement, absent strong grounds for non-enforcement of that agreement.

\section{(b) Does 'exclusive' mean unique?}

It is generally assumed that an exclusive jurisdiction agreement must be unique - that is, an agreement will only be exclusive if it nominates a single jurisdiction in which both parties agree to bring proceedings. ${ }^{53}$ An agreement that "Any disputes arising from this policy shall be referred to the Courts of England" is unique. ${ }^{54}$ It is comprehensive, in its application to all possible disputes and both parties. Unique exclusive agreements, if regularly enforced, create a high level of certainty and predictability about jurisdiction.

It has been suggested that a jurisdiction agreement need not be unique for it to be exclusive; ${ }^{55}$ that the parties can effectively nominate more than one court as having "exclusive" jurisdiction. There are two types of non-unique agreements. The first is

\footnotetext{
${ }^{50}$ Hague Convention, Art 6. The grounds on which the court can refuse to enforce the foreign choice of court agreement are if the agreement is null and void, if a party lacked capacity to conclude the agreement, if upholding the agreement would "lead to a manifest injustice or would be manifestly contrary to the public policy of the State of the court seised", if for exceptional reasons the agreement cannot be performed or if the selected court has determined not to hear the case.

${ }^{51}$ Recast, Art 31(2)-(3).

52 The right to invoke the court's discretion not to enforce a jurisdiction agreement cannot be waived.

${ }^{53}$ Lord Collins of Mapesbury (gen ed), Dicey, Morris \& Collins on the Conflict of Laws (London, Sweet \& Maxwell, 15 ${ }^{\text {th }}$ edn, 2012) ('Dicey, Morris \& Collins'), para 12R-098; BNP Paribas, supra $\mathrm{n}$ 33.

${ }^{54}$ This was the form of the jurisdiction clause in Akai Pty Ltd v The People's Insurance Co Ltd (1996) 188 CLR 418.

${ }^{55}$ Fawcett, supra n 32, 239-240 (referring in particular to options that allow one party or both parties to choose to litigate in one of two nominated forums).
} 
a Meeth v Glacetal clause - one which nominates one court exclusively for each party, excluding all of the otherwise competent courts for each party and obliging each party to litigate in its nominated court. The second type of non-unique agreement is one which nominates two or more courts as having exclusive jurisdiction for both parties. It has been suggested that the second type of non-unique agreement should be enforceable on the basis that the choice of several courts clearly excludes the jurisdiction of any other courts for both parties. ${ }^{56}$ But this argument ignores the important positive effect of exclusive agreements, namely, that each party is obliged to litigate, if at all, in the nominated court, ${ }^{57}$ and that there are remedial consequences for breaching that obligation by suing in any other court.

The positive effect of exclusive agreements - whether this results from the operation of law in protection of the agreement or the exercise of the court's discretion in upholding the parties' agreement - is incompatible with the second type of non-unique choice of court being treated as exclusive. ${ }^{58}$ The main problem that can be foreseen is that both types of non-unique clause create the potential for related proceedings to be brought in two courts, if each party invokes the "exclusive" jurisdiction of a different court. That diminishes the practical value of jurisdiction agreements in reducing uncertainty and the scope for jurisdictional disputes. In our opinion, the law should therefore discourage the use of non-unique agreements. Non-

\footnotetext{
${ }^{56}$ Hoffmann J in Kurz v Stella Musical GmbH broadly interpreted the concept of exclusivity under the Brussels Convention, reasoning that a clause need not designate a single jurisdiction for it to be exclusive provided that the clause had the effect of excluding the fora that would otherwise have jurisdiction by virtue of the convention: [1992] Ch 196, 203-204. Such an interpretation has been criticised: R Fentiman, "Jurisdiction - When Non-exclusive Means Exclusive" (1992) The Cambridge Law Journal 234. Magnus suggests that a clause need only exclude some courts that would otherwise be competent to be exclusive under the Regulation: Magnus, supra n 29, Art 23 para 145.

${ }^{57}$ Sherdley v Nordea Life \& Pension SA [2012] EWCA Civ 88; [2012] Lloyd's Rep IR 347 [7], [60][66].

${ }^{58}$ Magnus underscores this positive effect under the Regulation but does not explain how the positive effect is reconcilable with his previous assertion that an exclusive clause need only exclude some of the otherwise competent courts: supra n 29, Art 23 paras 145-146.
} 
unique clauses are, by definition, non-exclusive clauses, and should be treated as such.

(i) Hague Convention. The Hague Convention certainly applies only to unique ${ }^{59}$ exclusive agreements ${ }^{60}$ which select the courts of one country. An agreement which nominates the courts of more than one country as having "exclusive" jurisdiction is not exclusive under the Hague Convention. This leaves the effect of non-unique choice of court agreements to be resolved by the otherwise applicable regime. ${ }^{61}$

An agreement which nominates more than one court of the same country falls within the definition of an "exclusive" agreement under the Hague Convention. The national law of that country determines which of several selected national courts should have jurisdiction. ${ }^{62}$ Both types of non-unique clause would therefore be effective under the Hague Convention, but only if both courts are in the same country. ${ }^{63}$

(ii) Brussels instruments. It is unlikely that a non-unique agreement that nominates two or more courts as having exclusive jurisdiction for both parties (the second type referred to above) would be enforceable as an exclusive agreement under the Recast given that exclusivity requires the jurisdiction of all other competent Member State courts to be excluded for each party. ${ }^{64}$

\footnotetext{
${ }^{59}$ Brand and Herrup, supra $\mathrm{n} 22,17$.

${ }^{60}$ Hague Convention, Arts 1(1) and 3(a).

${ }^{61}$ In the European Union, the Brussels I Recast will apply to all conflicting exclusive agreements in Member States.

${ }^{62}$ Hartley and Dogauchi, supra n 18, para 103.

${ }^{63}$ See Ibid, paras 103-104; T Hartley, Choice of Court Agreements under the European and International Instruments (Oxford University Press, 2013), 144; Brand and Herrup, supra n 22, 43.

${ }^{64}$ See supra n 28 and accompanying text.
} 
In Meeth v Glacetal, the CJEU interpreted the Brussels Convention in light of the first type of non-unique exclusive clause that nominated two courts ${ }^{65}$ in different jurisdictions as having exclusive jurisdiction, depending on which party was claimant. It provided that "If Meeth sues Glacetal, the French courts alone shall have jurisdiction. If Glacetal sues Meeth, the German courts alone shall have jurisdiction". ${ }^{66}$ The CJEU ruled that the clause was permissible on the basis that it excluded the "other optional attributions of jurisdiction" under the Brussels Convention ${ }^{67}$ and because the Brussels Convention recognised "the independent will of the parties to a contract in deciding which courts are to have jurisdiction". ${ }^{68}$ The clause differentiated between the parties but did not discriminate against either party, ${ }^{69}$ in that each had the same rights to claim only in the other party's home courts and to be sued only in their home courts. ${ }^{70}$ This is less problematic than the second type of non-unique "exclusive" agreement because it is entirely exclusive from the perspective of each party: each party knows the only jurisdiction in which it can initiate and may be obliged to defend proceedings, and the jurisdiction of other competent Member State courts is excluded for each party. In that sense, a Meeth $v$ Glacetal clause is functionally equivalent to a unique exclusive agreement. For that reason, this type of clause would probably be regarded as effective under the Recast.

\footnotetext{
${ }^{65}$ Like the Hague Convention, an agreement which nominates more than one court of the same Member State falls within the definition of an "exclusive" agreement under the Brussels instruments. ${ }^{66}$ Meeth v Glacetal, supra $\mathrm{n} 28$.

${ }^{67} \mathrm{Ibid}, 2142$.

${ }^{68} \mathrm{Ibid}, 2141$.

${ }^{69}$ The Opinion of Advocate General Capotorti delivered on 12 October 1978 in Meeth v Glacetal Sarl, supra $\mathrm{n} 28$ refers at [2] to "the concern of the parties to establish a single criterion as being decisive: the domicile (or nationality) of the defendant".

${ }^{70}$ The CJEU stated that the Brussels Convention's recognition of the parties' "independent will...in deciding which courts are to have jurisdiction... applies particularly where the parties have by such an agreement reciprocally conferred jurisdiction on the courts specified in the general rule" (emphasis added): Meeth v Glacetal, supra n 28, 2141-2142.
} 
As we noted above, Meeth $v$ Glacetal clauses create the potential for related proceedings to be brought in two courts, if each party invokes the "exclusive" jurisdiction of a different court. Relevant to this problem is Recital 22(2) of the Recast which provides that "where the parties have entered into conflicting exclusive choiceof-court agreements, or where a court designated in an exclusive choice-of-court agreement has been seised first", the lis pendens rule protects the jurisdiction of the court first seised. ${ }^{71}$ The Council of the EU inserted Recital 22(2) without explanation, ${ }^{72}$ and it does not explicitly reflect any operative provision of the Recast. ${ }^{73}$

Two interpretations of recital 22(2) are open. The first is that it is a recital to Article 31(2), restricting the scope of the exception to the general rule of lis pendens for exclusive jurisdiction agreements. ${ }^{74}$ It seeks to mitigate the potential that the

\footnotetext{
${ }^{71}$ Recital 22(2) provides that the lis pendens rule applies "where $a$ court designated in an exclusive choice-of-court agreement has been seised first", which could imply that the exclusive choice-of-court agreement designates more than court (emphasis added). See G Cuniberti, "Choice of Court Agreements and Lis Pendens in the Brussels Ibis Regulation: a Critical Appraisal", in Georges Affaki and Horacio Grigera Naón (eds), Jurisdictional Choices in Times of Trouble (ICC, 2015) 203, 208.

${ }^{72}$ The text of recital 22(2) (in earlier drafts, recital 19) did not appear in the European Commission's proposal: European Commission, Proposal for a Regulation of the European Parliament and of the Council on Jurisdiction and the Recognition and Enforcement of Judgments in Civil and Commercial Matters (Recast) COM(2010) 748 final, 16 or in the European Parliament's draft response: Committee on Legal Affairs, European Parliament, Draft Report Proposal for a Regulation of the European Parliament and of the Council on Jurisdiction and the Recognition and Enforcement of Judgments in Civil and Commercial Matters (Recast), 28.05.2011, 47-48. It first appeared in Council of the European Union, Proposal for a Regulation of the European Parliament and of the Council on Jurisdiction and the Recognition and Enforcement of Judgments in Civil and Commercial Matters (Recast) - Draft recitals, JUSTCIV 209 CODEC1495, Brussels, 6 June 2012, 8.

${ }^{73}$ In support, see A Nuyts, "La refonte du règlement Bruxelles I" (2013) Revue critique de droit international prive 16,53 . Nuyts has suggested that recital 22(2) was intended to address the problem of each party invoking its own standard terms, in the situation that each set of standard terms contains an exclusive jurisdiction clause stipulating that a different court has "exclusive" jurisdiction to deal with the same dispute. If that be so, its solution to the problem of a jurisdictional battle of the forms is to provide a "first-seised" rule. This solution would give rise to myriad problems beyond the scope of this article, but particularly if one or both parties dispute the existence of either of the exclusive jurisdiction clauses.

${ }^{74}$ The scope and purpose of the exception to lis pendens, contained in Art 31(2), is explained in recital 22(1). The CJEU regularly uses recitals to interpret the scope and purpose of operative provisions in EU instruments. See eg Case C-288/97, Consorzio fra $i$ Caseifici dell'Altopiano di Asiago v Regione Veneto [1999] ECR I-2575, 2598, [19], [23]; Case C-298/00, Italy v Commission [2004] ECR I-4121,
} 
exception creates for proceedings in two courts with concurrent "exclusive" jurisdiction by requiring the court second seised - with jurisdiction under an agreement designating two courts with exclusive jurisdiction - to decline jurisdiction. On this interpretation, once a court is seised under a Meeth $v$ Glacetal clause, the clause becomes uniquely exclusive. The counter-party, which formerly had the exclusive right to bring claims before the other nominated court, must bring its claims and counter-claims before the court first seised. ${ }^{75}$ This interpretation is problematic because it contradicts ${ }^{76}$ the requirement that a court designated with exclusive jurisdiction must accept jurisdiction irrespective of when it was seised. ${ }^{77}$ Although it is consistent with the negative aspect of exclusivity, it is inconsistent with the positive.

An alternative interpretation of recital 22(2) is that it is an explanation of the lis pendens rule for concurrent "exclusive jurisdiction" contained in Article 31(1). ${ }^{78}$ On the one hand, the fact that the exception to lis pendens for exclusive jurisdiction agreements appears in Article $31(2)^{79}$ logically suggests that it is related to Article $31(1)$, although this may be the result of poor drafting given that the language of the

4164, [97]; Case C-509/09, eDate Advertising GmbH and Others $v$ X and C-161/10, Martinez v MGN Ltd (joined cases) [2011] ECR I-10269, [55]-[56].

${ }^{75}$ Nuyts similarly interprets recital 22(2) to mean that once a nominated court has been seised under the agreement, from that court's perspective there is no exclusive jurisdiction agreement requiring it to stay proceedings under the Art 31(2) exception and that the Art 31(2) exception is no longer available to the other nominated court: Nuyts, supra $\mathrm{n} 73,54$.

76 The CJEU observed in Case C-162/97, Criminal Proceedings against Nilsson, Hagelgren \& Arrborn, [1998] ECR I-7498, 7515 at [54] "that the preamble to a Community act has no binding legal force and cannot be relied on as a ground for derogating from the actual provisions of the act in question”. Similarly, in Case C-308/97, Giuseppe Manfredi v. Regione Puglia [1998] ECR I-7685, 7708 the CJEU ruled at [30] that a "recital cannot be relied upon to interpret [an] Article...in a manner clearly contrary to its wording".

${ }^{77}$ Recast, Art 25 and Art 31(2).

${ }^{78}$ Art 31(1) of the Recast provides that "Where actions come within the exclusive jurisdiction of several courts, any court other than the court first seised shall decline jurisdiction in favour of that court". Fentiman observed that Art 29 of the Regulation (which is equivalent to Art 31(1) of the Recast) arguably applies to non-unique exclusive clauses such that the court first seised takes the case: R Fentiman, International Commercial Litigation (Oxford University Press, 2010), para 11.73.

${ }^{79}$ And supplemented by Art 31(3). 
lis pendens rule contained in Article 29(1) suggests that Article 31(2) is properly an exception to it. ${ }^{80}$ On the other hand, it is uncertain whether Article 31(1) applies to prorogation by exclusive agreement or only to exclusive subject-matter jurisdiction. ${ }^{81}$ In the Recast, the term "exclusive jurisdiction" rather confusingly refers to both “exclusive jurisdiction" by prorogation ${ }^{82}$ and certain subject-matters as belonging to the "exclusive jurisdiction" of the courts of a particular state. ${ }^{83}$ A Member State court must not recognise a judgment if the jurisdiction of the court that rendered it conflicted with another court's exclusive subject matter jurisdiction, but it must recognise a judgment even if the court that rendered it exercised jurisdiction in conflict with an "exclusive jurisdiction" agreement. ${ }^{84}$ Further, the jurisdiction of a Member State court derived from the entry of an appearance by the defendant is deferred to the exclusive subject matter jurisdiction of another court ${ }^{85}$ but not to the exclusive jurisdiction of a court under an agreement. ${ }^{86}$ If recital 22(2) does show that Article 31(1) is intended to apply to Meeth v Glacetal clauses, then Article 31(1), providing a more specific rule, overrides the positive effect of exclusivity provided for by Article 25 for Meeth $v$ Glacetal clauses. The effect of this interpretation is that unique exclusive jurisdiction agreements have both a positive and negative effect under the Recast whereas Meeth $v$ Glacetal clauses have only a negative effect. The CJEU has not yet been called upon to interpret the Brussels instruments in light of a

\footnotetext{
${ }^{80}$ The wording of Art 29(1) makes this clear. The European Commission's proposal shows that Art 29 of the Regulation was simply renumbered as Art 32 (now, Art 31(1) of the Recast) and the exception to lis pendens was inserted as paragraph 2 to that provision: European Commission, Proposal for a Regulation of the European Parliament and of the Council on Jurisdiction and the Recognition and Enforcement of Judgments in Civil and Commercial Matters (Recast) COM(2010) 748 final, 37.

${ }^{81}$ Fentiman noted this uncertainty in respect of Art 29 of the Regulation: Fentiman, supra $\mathrm{n} 78$, para 11.72 .

${ }^{82}$ Art 25 of the Recast is contained in section 7, "Prorogation of jurisdiction".

${ }^{83}$ Section 6 of the Recast is entitled "Exclusive jurisdiction".

${ }^{84}$ Recast, Art 45(1)(e). The Regulation drew the same distinction: Art 35(1).

${ }^{85}$ Recast, Art 26(1).

${ }^{86}$ Art 31(2) of the Recast provides that it is "[w]ithout prejudice to Article 26".
} 
Meeth $v$ Glacetal clause creating multiple proceedings between two courts with "exclusive" jurisdiction. In Meeth $v$ Glacetal only one party commenced proceedings, so the court did not have to address this problem and the court did not refer to the possibility of that situation arising. ${ }^{87}$ An interpretation by the CJEU is all the more necessary under the Recast given the ambiguous relationship between Articles 25 and $31,{ }^{88}$ when applied to Meeth $v$ Glacetal clauses, which recital 22 does little to elucidate.

(iii) Common law. At common law, an agreement explicitly describing the jurisdiction of a court as "exclusive" is relevant to, but not determinative of, the question whether the agreement creates exclusive jurisdiction. Under current principles, the second type of non-unique agreement - an agreement under which both parties agree to the "exclusive" jurisdiction of more than one court - could not be treated as exclusive at common law.

This would certainly be so in the event that each party commenced proceedings in a different court nominated as having "exclusive" jurisdiction, assuming that each court treated the choices of jurisdiction as exclusive. This is the most likely scenario; history teaches us that however agreeable the parties are at the time of making the contract, they are likely to seek to exploit uncertainties and weaknesses in the jurisdiction agreement at the time the dispute arises. Parallel

\footnotetext{
${ }^{87}$ The Court was asked to consider whether the jurisdiction agreement precluded the defendant from setting off any of its claims in the forum in which the claimant was to be exclusively sued. The Court held that in the interests of "the need to respect individuals" right of independence" and "avoid[ing] superfluous procedure, which forms the basis of the Convention as a whole", Art 17 of the Brussels Convention could not be read as precluding a court seised under a reciprocal agreement from taking into account a set-off when raised as a defence, not as a counter-claim: Meeth $v$ Glacetal Sarl, supra $\mathrm{n}$ $28,2142[8]$.

${ }^{88}$ For an analysis of some other "wrinkles" in the Art 31(2) solution, see Briggs, supra n 21, para 4.350; F Garcimartin, "Lis Pendens and Exclusive Jurisdiction", in A Dickinson and E Lein (eds), The Brussels I Regulation Recast (Oxford University Press, 2015), paras 11.50-11.53; Heinze, supra $\mathrm{n} 43$, 590-591.
} 
proceedings could not be prevented, under current principles. A common law court may decline to exercise jurisdiction if there are strong reasons to do so, ${ }^{89}$ but even if the defendant had commenced proceedings first in another nominated jurisdiction, this may not be a sufficiently strong reason to refuse to enforce the agreement. In that case, both courts would refuse to stay proceedings, and may grant an antisuit injunction preventing the continuation of proceedings in the other nominated court or award damages for breach of contract.

In our view, non-unique agreements should be regarded as conferring nonexclusive jurisdiction on the nominated courts. This would mean that a nominated court would be unlikely to grant an anti-suit injunction restraining a party from continuing proceedings in another nominated court, and would be likely to stay its proceedings in favour of proceedings that had been commenced first in the other nominated court, resulting in a single set of proceedings.

In the less likely event that only one party invoked the "exclusive" jurisdiction of one of the nominated courts and the other party commenced proceedings in a third court, a non-unique exclusive agreement could be given effect at common law. The nominated court might well then grant an anti-suit injunction restraining proceedings in the third court. The fact that a non-unique agreement could be given effect in this circumstance is not a sufficient reason to treat such agreements as exclusive when the very scenario contemplated by the clause - both nominated courts being seised requires it to be treated as non-exclusive. It would be undesirable to treat such agreements inconsistently - that is, as exclusive when one nominated court and one non-nominated court are seised but non-exclusive when both nominated courts are

\footnotetext{
${ }^{89}$ Donohue v Armco Inc [2002] 1 All ER 749, 759; see above text to $\mathrm{n} 45$.
} 
seised. Such inconsistency would do little to encourage jurisdictional certainty and much to encourage jurisdictional litigation.

In the related context of a series of agreements (as distinct from one agreement) that nominate more than one court with "exclusive" jurisdiction, common law courts determine which should prevail, ${ }^{90}$ and then apply the normal rules relevant to the prevailing exclusive choice. ${ }^{91}$ In those cases, multiple clauses creating "exclusive" jurisdiction were not given effect simultaneously; one clause had to prevail over the others. This line of authority implies that a single clause stipulating that different courts had "exclusive" jurisdiction could not be given effect at common law; again, as a matter of interpretation, only one of those courts could be regarded as having exclusive jurisdiction. This obviously creates the need for a court to interpret the agreement to ascertain the effect it will be given, and this completely undermines the virtues of jurisdiction agreements in creating certainty and minimising jurisdictional disputes.

On the other hand, a Meeth $v$ Glacetal clause, which applies to the parties differently depending on which is claimant, may satisfy the definition of exclusivity and therefore may be effective at common law. ${ }^{92}$

\footnotetext{
${ }^{90}$ Garnett proposed that conflicting arbitration and exclusive jurisdiction agreements could be resolved by reference to which forum - of those the parties chose - was "more appropriate to resolve the dispute, with recognition to be given to the tribunal which has been first seised by a party": R Garnett, "Coexisting and Conflicting Jurisdiction and Arbitration Clauses" (2013) Journal of Private International Law 361, 370.

${ }^{91}$ In UBS AG \& IBS Securities LLC v HSH Nordbank $A G$, the parties had entered into a series of related contracts, which contained inconsistent "exclusive" jurisdiction clauses. Lord Collins held that the prevailing exclusive jurisdiction clause should be the one contained in "the agreements which are at the commercial centre of the transaction", on the basis that this would give effect to the parties' intention: [2009] EWCA Civ 585, [95]. See also Lornamead Acquisitions, supra n 19, [102]-[107].

${ }^{92}$ Briggs characterises this type of clause as non-exclusive: supra $\mathrm{n} 21$, para 4.189. However, applying the common law test of exclusivity to the parties separately (that is, whether the clause obliges each party to litigate only in the nominated court), it is an exclusive agreement.
} 


\section{Non-exclusive jurisdiction agreements}

A non-exclusive agreement is any agreement that is not exclusive. ${ }^{93}$ Most nonexclusive agreements are mutual, ${ }^{94}$ giving both parties the option to commence proceedings in a nominated forum. Under the Recast, and at common law, nonexclusive agreements have the same positive effect as exclusive agreements, in terms of establishing a court's jurisdiction, as discussed above. ${ }^{95}$ The difference between exclusive and non-exclusive agreements lies in their negative effects.

\section{(a) The negative effect of a non-exclusive agreement}

The negative effect of non-exclusive agreements is quite different to the negative effect of exclusive agreements. ${ }^{96}$ Non-exclusive jurisdiction agreements are optional, in that they do not oblige the parties to litigate in the nominated forum. ${ }^{97}$ Under the Recast, non-exclusive jurisdiction agreements are subject to the general rule for resolving conflicts of jurisdiction, namely, the lis pendens rule. ${ }^{98}$ At common law, non-exclusive jurisdiction agreements are merely one factor in the normal forum non

\footnotetext{
${ }^{93}$ Briggs states that "'Non-exclusive' means only that the jurisdiction agreement is not of the 'fully, bilaterally and immediately exclusive' type.": A Briggs, Agreements on Jurisdiction and Choice of Law (Oxford University Press, 2008), para 4.19.

${ }^{94} \mathrm{Cf}$ the observations of Giles CJ in FAI General Insurance supra $\mathrm{n} 33,126$ which suggest that lack of mutuality is a factor that might indicate that a jurisdiction clause is not exclusive. Although acknowledging that it was difficult to see why that was so, Giles CJ observed that "when taken with other matters mutuality may assist in finding a contractual intention that disputes shall be submitted only to the courts of the relevant jurisdiction": Ibid.

${ }^{95}$ See supra text to nn 39-47. As already noted, the Hague Convention does not apply to non-exclusive agreements. Although the convention does not regulate non-exclusive agreements at the jurisdictional stage, Art 22 allows Contracting States reciprocally to declare that their courts will recognise and enforce judgments issued by courts of other Contracting States which have been designated in a nonexclusive jurisdiction clause.

${ }^{96}$ The recognition in the Regulation that a jurisdiction agreement was only presumed to be exclusive was a significant change from the Brussels Convention which explicitly recognised non-exclusive jurisdiction clauses only in one situation, namely where the parties concluded the jurisdiction agreement for the sole benefit of one party. In obiter, the CJEU observed that that party retained the right to seise any court with jurisdiction under the Brussels Convention or the designated court: Art 17(5); Case 22/85, Anterist v Crédit Lyonnais [1986] ECR 1951, 1962-1963, [13]-[15]. This provision is discussed further below at text to nn 106-108.

${ }^{97}$ But see Sabah Shipyard, supra n 32, [37], [52].

${ }^{98}$ Recast, recital 22, Art 29(1).
} 
conveniens enquiry. ${ }^{99}$ Consequently, non-exclusive agreements are less likely than exclusive agreements to lead to a stay of proceedings.

\section{Unilateral optional agreements}

Although the law is built on the assumption that every jurisdiction clause can be characterised as either exclusive or non-exclusive, ${ }^{100}$ it is not uncommon to encounter jurisdiction clauses which purport to comprise both exclusive and non-exclusive elements and to apply to the parties differently. For example, the clause in Rothschild provided that:

"Any dispute which arises between the client and the Bank will be submitted to the exclusive jurisdiction of the courts of Luxembourg. The Bank nonetheless reserves the right to proceed against the client in the courts of the client's domicile or before any other court with jurisdiction in default of an election of the preceding jurisdiction". ${ }^{101}$

Such clauses are commonplace, particularly in international financial agreements. These clauses invariably favour the financial institution and are justified as a riskmanagement strategy, ${ }^{102}$ which reduces the price of finance for borrowers. ${ }^{103}$ They

\footnotetext{
${ }^{99}$ The right to invoke the court's discretion to stay proceedings on the grounds of forum non conveniens cannot, as a matter of law, be waived. For a discussion of whether this right can, as a matter of contract, be waived, see Briggs, supra $\mathrm{n}$ 93, para 5.39.

${ }^{100}$ D Joseph, Jurisdiction and Arbitration Agreements and their Enforcement (Sweet \& Maxwell, 2nd edn, 2010) para 4.03; Cf A Briggs, supra n 93 paras $4.24-4.25$ and 5.20 where he argues that "we cannot fit all agreements on jurisdiction into the categories of exclusive and non-exclusive: the nature of draftsmanship is more imaginative than these two categories can convey". Dicey, Morris \& Collins similarly suggests that "there is no reason why the parties may not, if so advised, make an agreement for the resolution of disputes which is more complex, and better suited to their needs, than would be provided by a plain and simple 'exclusive or non-exclusive' template": Dicey, Morris \& Collins, supra $\mathrm{n} 53$, para 12-108. It suggests at para 12-107 that the remedial consequences of one party bringing proceedings in a non-designated court need not turn on whether the clause is exclusive or nonexclusive.

${ }^{101}$ Rothschild, supra $\mathrm{n} 2$ (Ms Marshall's translation).

102 These clauses are intended to minimise what Fentiman calls "enforcement risk", one facet of which is "the risk that a judgment debtor with worldwide assets will disperse or conceal those assets". As he notes, "The extent of such risk depends on the effectiveness of jurisdiction agreements": Fentiman, supra $\mathrm{n} 20$, para 1.11 .
} 
indicate ex ante with certainty the jurisdiction in which the option holder can be expected to defend proceedings ${ }^{104}$ but enable it ex post to commence proceedings in another jurisdiction, if that will more favourably resolve its claims. The latter will generally be where the borrower's assets are located at the time litigation is commenced. This flexibility is desirable because the location of the debtor's assets may change during the course of the relationship. ${ }^{105}$ The non-option holder has $e x$ ante and ex post certainty as to the jurisdiction in which it can initiate proceedings but no certainty ex ante or ex post as to the jurisdiction in which it can be expected to defend proceedings.

Many of these clauses seem to be inspired by Article 17(5) of the Brussels Convention. ${ }^{106}$ While Article 17 provided that a jurisdiction agreement "shall be exclusive", it also provided that if the agreement "was concluded for the benefit of only one of the parties, that party shall retain the right to bring proceedings in any other court which has jurisdiction by virtue of this Convention."107 In such a case, the agreement was only exclusive from the perspective of the other party. From the beneficiary's perspective, the effect of Article 17(5) was that the agreement was nonexclusive, preserving the jurisdictional rights that the beneficiary would have had if there were no agreement.

\footnotetext{
${ }^{103}$ Fentiman, supra n 2, 24.

${ }^{104}$ Bouygues Offshore SA v Caspian Shipping Co (No 3) [1997] 2 Lloyd's Rep 493, 503.

${ }^{105}$ Briggs suggests this may be the justification for the parties' choice of non-exclusive jurisdiction generally: supra $\mathrm{n} 21$, para 4.423 .

${ }^{106}$ For example, M Ancel, L Marion and L Wynaendts, "Réflexions sur les clauses de juridiction

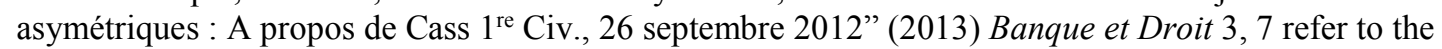
Rothschild clause as a "fatally ... truncated version of Article 17(5) of the [Brussels] Convention" (Ms Marshall's translation). The 1988 Lugano Convention contained an identical provision, which has since been removed. See infra text to nn 108-114 for discussion as to the effect of these clauses. ${ }^{107}$ Brussels Convention, Art 17(5).
} 
Unilateral optional jurisdiction clauses which explicitly create a similar effect

to Article 17(5) of the Brussels Convention were enforced by national courts under that Convention. ${ }^{108}$ Their effect under the Regulation and Recast, which contain no equivalent to Article 17(5), is more controversial. The French Cour d'Appel in Rothschild observed and several commentators ${ }^{109}$ have argued that although there is no equivalent to Article 17(5) in the Regulation, agreements concluded for the benefit of one party continue to have non-exclusive effect for the benefiting party under the Regulation. ${ }^{110}$ The provisions of the Regulation and Recast are not equivalent to the Brussels Convention in this respect, ${ }^{111}$ and other related respects, ${ }^{112}$ and comments in

\footnotetext{
${ }^{108}$ Ocarina Marine, supra $\mathrm{n} 3$.

${ }^{109}$ Ancel, Marion and Wynaendts, supra n 106, 7; D Martel, "A la découverte de la clause attributive de juridiction potestative" (2012) Recueil Dalloz 2876, 2878; Briggs, supra n 2, 139; D Draguiev, supra n 2, 38; Cf Ancel and Cuniberti, supra n 2, 9.

${ }^{110}$ The Court said: "[w]hile Article 23 of the Regulation does not, unlike Article 17 of the Brussels Convention 1968, envisage a clause stipulated in favour of one party, it does not affect the principle provided for by Article 17 of the Brussels Convention, namely: 'If the agreement conferring jurisdiction was concluded for the benefit of only one of the parties, that party shall retain the right to bring proceedings in any other court which has jurisdiction by virtue of this Convention"': Cour d'appel, Paris, 18.10.2011, RG n¹1/03572 (Ms Marshall's translation).

${ }^{111}$ Fentiman suggests that the relevant provisions of these instruments nonetheless operate equivalently. He argues that only the bilateral part of the agreement (the anchor) that designates a Member State court is governed by Art 25 of the Recast and that the option refers to courts with general or special jurisdiction: Fentiman, supra n 22, paras 2.130 and 2.135. If Art 25 governs only the anchor part of the agreement and if the effect of the Recast is to treat an agreement as exclusive if the parties have characterised it as such (notwithstanding the option), then it is difficult to see how the option holder could benefit from its option in circumstances where the non-option holder seeks to rely on the jurisdiction of the anchor court. The jurisdiction of the court the subject of the option, being based on special or general jurisdiction, will always be trumped by the exclusive jurisdiction of the anchor court if the non-option holder seises it: Recast, Art 31(2). If the non-option holder does not seise the anchor court and commences proceedings first in time in another Member State court with general or special jurisdiction, then the consequence of the option only being governed by the residual rules and not Art 25 is that the jurisdiction of the court seised first in time must prevail: Recast, Art 29. The only way that the jurisdiction of a court seised under the option could take priority to the exclusive jurisdiction of the anchor court is if the option and the bilateral part of the agreement are considered together as an Art 25 agreement.

${ }^{112}$ The Brussels Convention provided no exception to the general principle of lis pendens for exclusive jurisdiction clauses, which allowed Art 17(5) to function. The effect of the convention was that if the party for whose benefit the agreement was drafted seised a court with general or special jurisdiction first in time, the exclusive jurisdiction of the nominated court seised second in time by the nonbenefiting party had no effect by virtue of the lis pendens rule. Similarly, if the non-benefitting party seised the nominated court first in time, the jurisdiction of that court would prevail over the jurisdiction of a court with special or general jurisdiction subsequently seised by the benefitting party, again by virtue of the lis pendens rule. The Recast differs fundamentally from the convention because of the article 31(2) exception to lis pendens for exclusive jurisdiction agreements. If only the anchor agreement is governed by Art 25, and if by the operation of Art 25 this is exclusive, any proceedings
} 
obiter of the CJEU interpreting Article 17(5) should therefore not be relied upon in interpreting different principles. ${ }^{113}$ This was the issue that arose in Rothschild and ICH v Crédit suisse, which both concerned a clause in similar terms to Article 17(5) but which allowed the beneficiary of the clause also to seise non-Member State courts. ${ }^{114}$ As we explain further below, in both cases, the Cour de cassation held that these clauses were unenforceable.

Unilateral optional clauses are outside the scope of the Hague Convention, ${ }^{115}$ which requires an agreement to be exclusive irrespective of the procedural positions of the parties. ${ }^{116}$ This leaves significant scope for argument as to the effect of unilateral optional agreements under the Recast as well as national laws. In the following sub-sections, we analyse the treatment of asymmetric agreements by French courts in several recent cases, applying the Regulation, and by English courts, applying the common law and the Brussels and Lugano Conventions.

\footnotetext{
by the non-option holder - whether commenced first or second in time - will be deferred to the jurisdiction of the anchor court so long as the non-option holder seises it. On the application of Art 31(2) to unilateral optional clauses, see generally, I Bergson, "The Death of the Torpedo Action? The Practical Operation of the Recast's Reforms to Enhance the Protection for Exclusive Jurisdiction Agreements within the European Union" (2015) Journal of Private International Law 1, 22.

${ }^{113}$ In Case C-189/08, Zuid-Chemie BV v Philippo's Mineralenfabriek NV/SA [2009] ECR I-6917 at

[18] the CJEU ruled that: “....in so far as Regulation No 44/2001 replaces, in the relations between Member States, ... ('the Brussels Convention'), the interpretation provided by the Court in respect of the provisions of the Brussels Convention is also valid for those of Regulation No 44/2001 whenever the provisions of those Community instruments may be regarded as equivalent". We assume that this principle will similarly apply to the Recast.

${ }_{114}^{11}$ See infra text to nn 117-138.

${ }^{115}$ Switzerland proposed that unilateral agreements should be brought within the scope of the Hague Convention. This proposal was rejected. See Hague Conference, Proceedings of the Twentieth Session, Commission II, Tome III, Choice of Law, Minutes No 3, para 2 and 9.

${ }^{116}$ Hartley and Dogauchi, supra n 18, para 106.
} 


\title{
1. French courts
}

\author{
(a) Rothschild
}

On 20 December 2006, Madame $X^{117}$ opened a bank account with the Banque Privée Edmond de Rothschild Europe (Bank) through the Compagnie Finançière Edmond de Rothschild (French Branch). The Bank, seated in Luxembourg, and the French Branch, seated in Paris, both form part of the Edmond de Rothschild group. On opening the account, Madame $\mathrm{X}$ signed a number of agreements ${ }^{118}$ including the Bank's general conditions agreement for the opening of the account. Madame $\mathrm{X}$ deposited $€ 1.7$ million into the account.

Clause 27-2 of the general conditions agreement relevantly provided:

\author{
"Any dispute which arises between the client and the Bank will be submitted to \\ the exclusive jurisdiction of the courts of Luxembourg. The Bank nonetheless \\ reserves the right to proceed against the client in the courts of the client's \\ domicile or before any other court with jurisdiction in default of an election of \\ the preceding jurisdiction". ${ }^{119}$
}

\footnotetext{
117 The Cour de cassation refers to Madame Férielle X as "Madame X" so this is what she is called in most of the commentaries on this case.

118 These included a request for Lombard Credit, a credit card request, a "statement of an economic beneficiary", and an agency agreement, which governed the relationship between the Bank and the French Branch. The agency agreement provided that "the customer [Madame X] releases the Bank, with respect to the agent [the French Branch], from the obligation under Luxembourg law to maintain bank-client confidentiality and accepts that all documents consulted or collected by the agent are deemed to be consulted or collected by the agent. The customer authorises the agent to monitor account activity and verify the balance of the account. However, the customer does not authorise the agent to access account securities, deposits or holdings/assets or to dispose of them in any manner whatsoever or to give instructions in relation to their management or administration" (Ms Marshall's translation).

${ }^{119} \mathrm{It}$ is not clear from the face of the clause whether the phrase "an election of the preceding jurisdiction" refers to the courts of the client's domicile or an election of the courts of Luxembourg. The agency agreement between the French Branch, the Bank and Madame X contained a similar jurisdiction clause which provided that: "all disputes will be submitted to the exclusive jurisdiction of the courts of Luxembourg. The Luxembourg courts have jurisdiction instead of the courts of the place of the institution of the Bank through which the account is opened. The client nonetheless authorises the Bank to proceed before any other court which would have jurisdiction in the absence of the choice of the preceding jurisdiction and notably in the domicile of the client or the domicile of the agent" (Ms
} 
Although Madame X was plainly a consumer according to the Regulation, ${ }^{120}$ because the Bank seemingly did not direct its activities towards Madame X's place of domicile, ${ }^{121}$ Spain, ${ }^{122}$ the Regulation's jurisdictional rules that protect passive consumers did not apply. ${ }^{123}$ The clause was therefore governed by Article 23 of the Regulation.

On 16 October 2009, owing to significant losses on her investments, Madame $\mathrm{X}$ claimed against the Bank and French Branch in the Tribunal de grande instance, the court of first instance, in Paris. ${ }^{124}$ She claimed that the Bank was liable for the capital loss on her investment; that the Bank and French Branch had failed to fulfil their obligations to provide her with adequate information and advice prior to investing her funds; and that they had improperly levied agency fees and fees for the provision of financial services. Madame $\mathrm{X}$ argued that the Tribunal de grande instance had jurisdiction to hear her claims against both the French Branch and the Bank: the court had jurisdiction over the French Branch by virtue of the French

\footnotetext{
Marshall's translation). Cour d'appel de Versailles, 1ère Ch. A., 26.09.1991, Bruno v Société Citibank, (1992) Revue critique du droit interational privé 333, 334 contained a similar optional derogation clause between a bank and a consumer. It provided for the courts of Monaco to have jurisdiction but reserved to the bank the right to bring proceedings before any other court with jurisdiction. The optional nature of the clause was not directly in issue.

${ }^{120}$ The Regulation defines a consumer as a person concluding a contract "for a purpose which can be regarded as being outside his trade or profession": Art 15(1).

${ }^{121}$ Regulation, Art 15(1)(c). For a recent consideration of Art15(1)(c), see Case C-218/12, Lokman Emrek v Vlado Sabranovic EU:C:2013:666.

122 The report of the Cour d'appel states that Madame X's place of domicile was Spain. While this could be restricted to her place of domicile at the time of the litigation, it is likely that she was also domiciled in Spain at the time she opened the bank account hence the reason why she fell outside the protective provisions of the Regulation.

${ }^{123}$ If Art 16 of the Regulation had been applicable, Madame X could have sued the Bank in either the Bank's place of domicile or her own, and be sued only in her place of domicile.

${ }^{124}$ Madame X pointed to the following connecting factors: the French Branch is agent of the Bank; the two companies are intrinsically intertwined both in terms of their name and their position with respect to their clients; their omissions arose from identical facts; and they both failed to fulfil their contractual obligations. Rothschild, supra n 2 (see the court's conclusion on the second ground of appeal in the final paragraph of the judgment.) (Ms Marshall's translation).
} 
Branch's domicile ${ }^{125}$ and derived jurisdiction over the Bank by virtue of the close connection between Madame X's claims against both defendants. ${ }^{126}$

The Bank objected to jurisdiction on the basis that Madame $\mathrm{X}$ was bound by the first limb of the jurisdiction clause which provided for exclusive jurisdiction of the courts of Luxembourg in litigation initiated by the customer. The Tribunal de grande instance dismissed the objection to jurisdiction and set aside the clause in its entirety. It held that:

“... [A]ccording to the terms of the clause, because the Bank reserved the right to bring proceedings in the domicile of Madame X...or before 'any court with jurisdiction' (which means the jurisdiction of any country, whether Member States of the European Union or not), the clause obliged only Madame X to seise the courts of Luxembourg and gave the Bank a 'very large discretionary choice'. The clause is, accordingly, contrary to the objective and the purpose in prorogation of jurisdiction which Article 23 of the Regulation envisages. Article 23 of the Regulation makes predictability in the rules of jurisdiction a direct consequence of the principle of legal certainty. This principle is so foundational to the Regulation that the clause must be set aside." 127

The Bank appealed to the Cour d'appel on the basis that the jurisdiction clause complied with the Regulation to the extent that: both parties were domiciled in a Member State; the part of the clause concerning the election of the courts of the client's domicile was referable to a Member State; that Article 23 allows for a jurisdiction clause which is either bilateral or unilateral; and that Article 23 does not set as a condition for the validity of a jurisdiction clause that only the designated court

\footnotetext{
${ }^{125}$ Regulation, Art 2(1).

${ }^{126}$ Regulation, Art 6(1).

${ }^{127}$ Tribunal de grande instance, Paris, 18.01.2011, RG nº9/16659, 5 (Ms Marshall's translation) (emphasis added).
} 
may be seised. ${ }^{128}$ Madame $\mathrm{X}$ sought to have the decision setting the clause aside upheld on the basis that it did not comply with the Regulation. She contended that the parties had not agreed that the courts of a Member State would have jurisdiction because the stronger party, the Bank, had the freedom to bring claims wherever it pleased.

The Cour d'appel dismissed the appeal and upheld the decision of the Tribunal de grande instance. The Cour d'appel relevantly stated that:

"[E]ven if th[e] principle from Article 17 of the Brussels Convention validates clauses (which clearly express a common willingness to favour one of the parties), the principle does not allow for a clause to give to one party complete discretion to choose whatever jurisdiction it pleases... It follows that, on that basis, [the Tribunal de grande instance] was correct in finding that the clause was contrary to the objective and the purpose in prorogation of jurisdiction referred to in Article 23 of the Regulation." 129

The Bank appealed to the Cour de cassation. It argued that the Regulation allowed for a clause drafted in favour of one party and that, having regard to the purpose of the clause, it was fully consistent with the objectives of predictability and certainty promoted by Article 23 of the Regulation. The Bank objected to the literal reading of the clause by the Cour d'appel, asserting that the court erred in having concluded that the effect of the clause was to allow for one party to have complete discretion to choose whatever jurisdiction it pleases. This argument was premised on the words "any other court with jurisdiction" 130 being construed to mean "any other court with

\footnotetext{
${ }^{128}$ Cour d'appel, Paris, 18.10.2011, RG n¹1/03572.

${ }^{129}$ Ibid (Ms Marshall's translation) (emphasis added).

130 The phrase in French is "tout autre tribunal compétent".
} 
jurisdiction by virtue of the Regulation". ${ }^{131}$ On its preferred construction, the Bank further submitted that, in reserving to the Bank the right to proceed against the customer in the courts of the customer's domicile or before any court (of a Member State) with jurisdiction, "it deferred to the rules of international jurisdiction as provided by the Regulation in the event that the beneficiary of the clause failed to seise the courts of Luxembourg". ${ }^{132}$ Finally, the Bank submitted that the court erroneously had regard to the second limb of the clause (ie the Bank's option) in circumstances where only the first limb of the clause (ie Madame X's obligation to seise the courts of Luxembourg) was in issue.

The Cour de cassation dismissed the appeal. Its brief reasons for judgment are as follows:

"Having construed the clause to mean that, in reserving the right to the Bank to proceed in Madame X's place of domicile or before any other competent tribunal, only Madame X was bound to the obligation to seise the courts of Luxembourg, the Cour d'appel correctly concluded that the clause had a potestative character ${ }^{133}$ with respect to the bank such that it was contrary to the objective and purpose in prorogation of jurisdiction, referred to in article 23 of the Regulation." ${ }^{134}$

(b) ICH v Crédit suisse

\footnotetext{
${ }^{131}$ On the construction for which the appellants contended, the French phrase would have read "tout autre tribunal compétent en vertu du présent règlement".

${ }^{132}$ Rothschild, supra $\mathrm{n} 2$ (Ms Marshall's translation). The Bank seemingly appealed to the fact that the court might be more willing to uphold a clause that reflected the default rules under the Regulation.

${ }^{133}$ We suggest that the court's use of the adjective "potestative" was merely descriptive. In holding that the clause was contrary to the Regulation's objective and purpose because of the significant discretion it afforded to the Bank, the court likened the clause, albeit not explicitly, to a substantive contractual clause that has a potestative character under French national law i.e. it is conditioned completely on the will of the promisor.

${ }^{134}$ Rothschild, supra n 2 (Ms Marshall's translation).
} 
The Cour de cassation has followed its approach in Rothschild in its recent decision of 25 March 2015. ${ }^{135}$ The court's reasoning again focused on the disparity that the unilateral optional clause created between the parties. ${ }^{136}$ The case involved a dispute between Danne, a French company, and Danne's English agent, NJRH Management and its representative (NJRH); Société Générale (SG), seated in Paris; and Crédit suisse, seated in Zurich, concerning a financing package under which returns on Danne's investment were to be used to repay its secured loan to Crédit suisse, guaranteed by SG. The credit facility agreements concluded between Danne and Crédit suisse contained a jurisdiction agreement which provided that:

"The borrower acknowledges that the exclusive forum for all proceedings is Zurich or the place of the bank's branch where the relationship between the parties was formed. The bank nonetheless reserves the right to commence proceedings against the borrower before any other court with jurisdiction." ${ }^{137}$

The investments yielded low returns and Société civile immobilière ICH (ICH), the successor in law to Danne, brought proceedings against NJRH Management and the banks before the Tribunal de grande instance d'Angers, alleging that they had proposed a structurally unviable financial package and failed to fulfil their obligations to provide Danne with adequate information and advice. The tribunal declared itself incompetent on the basis that neither the banks nor NJRH were domiciled within its jurisdiction and in light of the relevant jurisdiction agreement.

\footnotetext{
${ }^{135}$ ICH v Crédit suisse, supra $\mathrm{n} 5$. The case involved Art 23 of the 2007 Lugano Convention, which was identical to Art 23 of the Regulation. The Lugano Convention applies to jurisdiction agreements designating a non-EU Lugano Convention state, in this case, Switzerland: Art 64(2)(a).

${ }^{136}$ See B A Marshall, "Imbalanced Jurisdiction Clauses under the Lugano Convention: Judgment of the French Cour de cassation of 25 March 2015" (forthcoming) Zeitschrift für Europäisches Privatrecht.

${ }^{137}$ Ibid (Ms Marshall's translation).
} 
The Cour d'appel d'Angers confirmed the tribunal's decision holding that the indivisibility of ICH's claims required that they be adjudicated by a single tribunal and, because neither NJRH nor SG objected to the matter being heard in the courts designated by the jurisdiction clause, that the matter should be heard by the courts of Switzerland. The Cour d'appel addressed the unilateral nature of the clause briefly, holding that the "imbalance, concomitant with a jurisdiction clause between two contracting parties from different countries, does not suffice to make it irregular under the Lugano Convention". The Cour de cassation quashed the decision, reasoning that:

"In holding, without exploring such imbalance, that the jurisdiction clause - which reserved to the bank the right to proceed against the borrower before any court with jurisdiction and which did not specify the objective elements on which this alternative jurisdiction was based - was not contrary to the objectives of predictability and legal certainty of the aforementioned convention, the decision of the Cour d'appel is without a legal basis." 138

\section{(c) Apple v eBizcuss}

The Regulation's objective in permitting jurisdiction clauses that produce certainty was liberally interpreted by the Cour d'appel de Paris in its decision of 8 April $2014{ }^{139}$ concerning a dispute between Apple Sales International, seated in Ireland, and eBizcuss (in liquidation), an authorised reseller of Apple products, seated in Paris. eBizcuss initiated proceedings against Apple in the Tribunal de commerce de Paris, the court of first instance, alleging that Apple had created a relationship of commercial economic dependence with eBizcuss which it had abused by giving

\footnotetext{
${ }^{138}$ ICH v Crédit suisse, supra n 5 (Ms Marshall's translation).

${ }^{139}$ Cour d'appel, Paris, 08.04.2014, RG n¹3/21121.
} 
preferential treatment to its own Apple Stores. The tribunal declared itself incompetent on the basis of the relevant jurisdiction agreement which provided that:

"the parties shall submit to the jurisdiction of the courts of the Republic of Ireland. Apple reserves the right to institute proceedings against Reseller in the courts having jurisdiction in the place where Reseller has its seat or in any jurisdiction where a harm to Apple is occurring". ${ }^{140}$

eBizcuss appealed to the Cour d'appel arguing, inter alia, that enforcement of the clause would run counter to the objective of certainty under the Regulation. ${ }^{141}$ The court rejected this argument, holding that the clause was certain in that it allowed for the identification of the jurisdictions before which eventual disputes concerning the performance and interpretation of the contract might be brought. eBizcuss is currently the subject of an appeal before the Cour de cassation.

Despite their opposing outcomes, in Rothschild and ICHv Crédit suisse on the one hand and eBizcuss on the other, the French courts construed the agreement as a whole and determined its overall effectiveness by reference to the objectives of the Brussels and Lugano regime.

In both Rothschild and ICH v Crédit suisse the bank's jurisdictional option had not been exercised. The objection to jurisdiction was in relation to a breach by the non-option holder of the first, mutual limb of the clause. The Cour de cassation in Rothschild interpreted the clause to be objectionable on the basis that the clause, considered in its entirety, conferred an unreciprocated advantage on one party to choose the jurisdiction, which was left to its complete discretion. This lack of

\footnotetext{
${ }^{140}$ Ibid (Ms Marshall's translation).

${ }^{141}$ From the reasons for judgment, it appears that neither the parties nor the court referred to the decision of the Cour de cassation in Rothschild.
} 
symmetry seems to have been a significant factor in the court's decision not to enforce the clause as against the customer in Rothschild and was certainly a significant factor in the court's decision in ICH v Crédit suisse. In both cases, the court considered the imbalanced and unlimited optional character of the clause to be contrary to Article 23's objective of certainty and predictability. Given that the compatibility of unilateral optional agreements with Article 23 is not an acte clair, the Cour de cassation has been criticised ${ }^{142}$ for not referring the matter in Rothschild to the CJEU for a preliminary ruling ${ }^{143}$ These cases are nonetheless clearly authoritative in France, and the Cour de cassation is the highest court of a Member State to date to rule consistently on this issue. ${ }^{144}$ It seems likely that the same objections to enforcement of a unilateral optional clause would mean that such a clause would not be enforced in France under the Recast.

The clause in eBizcuss is obviously somewhat different to that in the two Cour de cassation cases, because it limits the scope of the option to a jurisdiction where harm to the option holder is occurring. Arguably, this constitutes "an objective element on which alternative jurisdiction is based", to which the Cour de cassation referred in $\mathrm{ICH} v$ Crédit suisse, which may influence how the Cour de cassation will construe the imbalance that the clause creates. That having been said, the reference to the place of any harm is unlimited and seems to create the possibility of concurrent proceedings. These factors might lead the Cour de cassation to conclude that the clause is not sufficiently certain having regard to the objectives of Article 23 of the Regulation.

\footnotetext{
${ }^{142}$ See eg Fentiman, supra n 2, 26.

${ }^{143}$ Treaty on the Functioning of the European Union, Art 267(1)(b) and (3).

${ }^{144}$ The highest court in Italy has enforced a unilateral optional clause, albeit drafted in different terms to the clauses in Rothschild and ICH v Crédit Suisse: see Cass, S.U., 8 March 2012, No 3264 (Umbro International Ltd $v$ Global Brand Management Srl). The Italian court did not refer the matter to the CJEU for a preliminary ruling.
} 


\section{English courts}

English courts have taken a very different approach to French courts to optional agreements. This approach, which is well-established, ${ }^{145}$ assumes that unilateral optional agreements are legitimate and therefore that they should be enforced. ${ }^{146}$ In most cases in which the issue has arisen, the English courts have held that the option holder's entitlement to exercise its option prevails over the non-option holder's rights. 147 Until recently, the non-option holder rarely challenged the clause on the basis of its optional nature. In the following subsections, we describe the leading decision of the English Court of Appeal, as well as several of the more prominent first instance decisions.

(a) Continental Bankv Aeakos Compania Naviera (Continental Bank)

The leading English authority on asymmetrical optional agreements is the 1993 decision of the English Court of Appeal, applying the Brussels Convention, in Continental Bank. The jurisdiction clause relevantly provided that "Each of the borrowers...hereby irrevocably submits to the jurisdiction of the English courts...but the bank reserves the right to proceed under this agreement in the courts of any other

\footnotetext{
${ }^{145} S \&$ W Berisford plc v New Hampshire Insurance Co [1990] 2 All ER 321, 326 (Hobhouse J noting in passing that "It is of course possible" for exclusive jurisdiction clauses to impose a contractual obligation on only one of the parties to litigate in the nominated jurisdiction).

${ }^{146}$ Armadora Occidental, supra n 3; The “Iran Vojdan”, supra n 3; Du Pont v Agnew, supra n 3; Ocarina Marine, supra n 3; Commercial Union Assurance Co Plc v NRG Victory Reinsurance Ltd [1998] 1 Lloyd's Rep 80; BP plc v National Union Fire Insurance Co [2004] EWHC 1132; Heath Lambert Ltd v Sociedad de Corretaje de Seguros [2004] 1 Lloyd's Rep 495; King v Brandywine Reinsurance Co (UK) Ltd [2004] 2 CLC 981 (QB).

${ }^{147}$ NB Three Shipping Ltd v Harebell Shipping Ltd [2004] EWHC 509 (QB); [2005] 1 Lloyd's Rep 509; Law Debenture Trust Corporation Plc v Elektrim Finance BV \& Ors [2005] EWHC 1412 (Ch); [2005] 2 Lloyd's Rep 755; Catlin Syndicate Ltd v Adams Land \& Cattle Co [2006] EWHC 2065 (Comm), [2006] 2 CLC 425, paras 39-40. Cf Lornamead Acquisitions, supra n 19, [112]. In Dubai Electricity Co v Islamic Republic of Iran (The "Iran Vojdan"), Bingham J held that the non-option holder could protect itself against commencing abortive proceedings by requesting an exercise of the option: supra $\mathrm{n} 3,385$.
} 
country claiming or having jurisdiction in respect thereof." ${ }^{148}$ The borrowers commenced proceedings in the Greek courts, and the bank applied in the English courts for an antisuit injunction to restrain the continuation of the Greek proceedings. The issue was whether the clause was exclusive so far as the borrowers were concerned. The Court of Appeal noted that the clause was not exclusive so far as the bank was concerned and, taking that factor into account, held that it was exclusive so far as the borrowers were concerned. ${ }^{149}$ The borrowers did not challenge the asymmetric or optional nature of the jurisdiction agreement, and the court clearly assumed that such a clause was enforceable against the non-option holder.

\section{(b) Lornamead Acquisitions Ltd v Kaupthing Bank HF (Lornamead Acquisitions)}

The jurisdiction clause in this case, which was governed by the 1988 Lugano Convention, was similar to that in Continental Bank. It stipulated that "The courts of England have exclusive jurisdiction to settle any dispute arising out of or in connection with this Agreement", but also provided that this clause "was for the benefit of the Finance Parties and Secured Parties only" and therefore that "no Finance Party or Secured Party shall be prevented from taking proceedings relating to a Dispute in any other courts with jurisdiction." 150 The non-option holder (Lornamead) commenced proceedings in England and the option holder (Kaupthing) challenged the English court's jurisdiction. Gloster J held that Article 17 of the Lugano Convention, which at the relevant time was the same as Article 17 of the Brussels Convention, ${ }^{151}$ did not entitle the option holder "unilaterally to challenge proceedings previously brought by Lornamead against Kaupthing in England in

\footnotetext{
148 Continental Bank, supra n 31, 591-592.

149 Ibid, 594.

${ }^{150}$ Lornamead Acquisitions, supra n 19.

151 See supra text to nn 106-114.
} 
accordance with the terms of the English jurisdiction clause". ${ }^{152}$ The option holder did not dispute that the effect of the lis pendens rule in the Lugano Convention was that once proceedings had been commenced in England in accordance with the jurisdiction agreement, the option holder lost its option to bring proceedings in another court. ${ }^{153}$

\section{(c) NB Three Shipping v Harebell Shipping (NB Three Shipping)}

The charterparty the subject of the litigation in this case contained a unilateral, dual dispute resolution optional clause ${ }^{154}$ which provided that: "[ $[\mathrm{t}]$ he Courts of England shall have jurisdiction to settle any disputes which may arise out of or in connection with this Charterparty but the owner shall have the option of bringing any dispute hereunder to arbitration". ${ }^{155}$ Pursuant to the first, mutual limb of the clause, the charterer commenced proceedings in an English court. The owners sought a stay of the English proceedings under national arbitration legislation ${ }^{156}$ and, in reliance on their option, to refer the dispute to arbitration. ${ }^{157}$ Applying English law, Morison J construed the commencement of proceedings by the charterers in accordance with the jurisdiction clause as a bypassing of the owners' option to determine that disputes be resolved by arbitration. His Honour held that the owners could exercise the option even after the charterers had commenced proceedings.

\footnotetext{
${ }^{152}$ Lornamead Acquisitions, supra n 19, [112].

${ }^{153} \mathrm{Ibid},[112]$.

${ }^{154}$ His Honour considered the hybrid clause in isolation and did not have regard to the enforceability of the other jurisdictional options granted to the option holder under the charterparty. These clauses conferred on the owners the option to bring disputes before the courts of England, any other court which had jurisdiction by virtue of the Brussels Convention, any other court which had jurisdiction by any convention covered by Art 57 of the Brussels Convention or "any court in an any country or territory in which the property of the charterer is situated" (emphasis added).

${ }^{155}$ NB Three Shipping, supra $\mathrm{n} 147$.

${ }^{156}$ Arbitration Act 1996.

${ }^{157}$ Section 9(1) of the Arbitration Act 1996 is in the following terms: "A party to an arbitration agreement against whom legal proceedings are brought (whether by way of claim or counterclaim) in respect of a matter which under the agreement is to be referred to arbitration may (upon notice to the other parties to the proceedings) apply to the court in which the proceedings have been brought to stay the proceedings so far as they concern that matter".
} 
In NB Three Shipping, the owners' option was in effect "not circumscribed by any time constraint or formality". ${ }^{158}$ The exercise of the option took effect retrospectively and deprived the non-option holder of the ability to bring any disputes in the designated forum until such a time as the option holder had exercised its option or communicated that it had chosen not to do so. Morison J noted without demur that the clause was "designed to give 'better' rights to owners than charterers." 159

\section{(d) Law Debenture Trust Corporation v Elektrim Finance (Law Debenture)}

The unilateral optional jurisdiction clause in Law Debenture ${ }^{160}$ was a dual dispute resolution clause comprising both what was described as an "exclusive" agreement to submit disputes to arbitration and a unilateral option given to the claimant to seise the national courts of the arbitral forum. ${ }^{161}$ The non-option holders commenced arbitral proceedings first, and the option holder then commenced proceedings in the English courts. The issue was whether the court proceedings should be stayed under national arbitration legislation. ${ }^{162}$ Mann J refused to stay proceedings, holding the clause to be valid. His Honour rejected the construction advanced by the defendants that the option ceased to be available once the non-option holder initiated arbitration

\footnotetext{
${ }^{158}$ Submission of Counsel for the Charterers NB Three Shipping, supra n 147, 512.

${ }^{159}$ NB Three Shipping, supra n 147, 514.

${ }^{160}$ Law Debenture, supra $\mathrm{n} 147$.

${ }^{161}$ The clause (clause 29.2) provided that "any dispute... may be submitted by any party to arbitration...[Clause 29.4] [at] London... [Clause 29.6:] The agreement...to refer all disputes...to arbitration...is exclusive such that neither [of the defendants] shall be permitted to bring proceedings in any other court or tribunal other than by way of counterclaim...[Clause 29.7:] Notwithstanding clause 29.2, for the exclusive benefit of the [claimant] [the defendants]....agree that the [claimant] shall have the exclusive right, at their option, to apply to the court of England, who shall have non-exclusive jurisdiction...[Clause 29.8(A)] [The defendants] waive objection to the English courts on grounds of inconvenient forum...": Ibid, 757-758. The clause was similar in this respect to the clause in Russkaya Telefonnaya, supra $\mathrm{n} 4$.

162 Arbitration Act 1996 (UK).
} 
proceedings. ${ }^{163}$ His Honour said, "I have difficulty in seeing any arguable limits, let alone any substantive limits, on the rights of [the option holder]". ${ }^{164}$ His Honour accepted that the option holder would probably forgo its option were it to commence arbitration or "participate sufficiently" in an arbitration commenced by the non-option holder. ${ }^{165}$

Mann J found that the use of the word "exclusive" in the first, mutual limb of the clause was not an "entirely comfortable" one but was clear from its context. He interpreted it to mean exclusive with respect to the non-option holders. In other words, the non-option holders "can be forced to arbitrate (unless litigation is started, in which case they can counterclaim)". ${ }^{166}$

Unlike the defendants in Continental Bank, ${ }^{167}$ the non-option holders in Law Debenture $^{168}$ did submit that the asymmetrical impact of the clause was relevant in determining the effect of the agreement. His Honour addressed this point only briefly, observing that it is not "correct to say that the provisions are somehow less than even handed in any relevant way. They give an additional advantage to one party but so do many contractual provisions". 169

\footnotetext{
${ }^{163}$ Law Debenture, supra n 147, 767. Counsel for the defendants submitted that the option in clause 29.7 amounted to a right on the part of the option holder to commence court proceedings if it did so before the other party had commenced arbitration proceedings covering the same subject matter.

${ }^{164}$ Ibid, 767.

165 Ibid, 767.

${ }^{166}$ Law Debenture, supra n 147, 767.

${ }^{167}$ Continental Bank, supra n 31.

${ }^{168}$ Law Debenture, supra n 147.

${ }^{169}$ Ibid, 768.
} 
The unilateral optional jurisdiction clause in Mauritius Commercial Bank, ${ }^{170}$ which fell outside the Brussels I Regulation, the parties being domiciled in India and Mauritius, ${ }^{171}$ stipulated that the English courts had "exclusive jurisdiction", but reserved the right to one party to commence proceedings in "any other courts in any jurisdiction". The option holder commenced proceedings in England and the nonoption holder challenged the English courts' jurisdiction on the basis that the effect of the option - binding the non-option holder to litigate anywhere in the world - was so unreasonable as to be invalid according to English public policy. Applying English law, Popplewell J interpreted the clause to refer to "any court which would regard itself as of competent jurisdiction", ${ }^{172}$ and held that it was effective. His Honour observed in obiter, referring to the reasoning in Rothschild, that even if the clause were to be interpreted as allowing the option holder to commence proceedings in any court in any jurisdiction, this would still have been enforceable on the basis that the parties agreed to it. ${ }^{173}$

In comparison to the French cases, the English decisions take a much stricter approach to enforcing the parties' expressed choices. Unilateral options are regarded as enforceable and legitimate, and the asymmetric nature of the agreement is not regarded as being a cause for concern, much less a ground for non-enforcement. In the cases referred to above, the court applied either the Brussels or Lugano

\footnotetext{
${ }^{170}$ Mauritius Commercial Bank, supra n 3. This was a first instance decision before Popplewell J.

${ }^{171}$ If an analogous case were now to arise, it would be regulated by the Recast.

${ }^{172}$ Mauritius Commercial Bank, supra n 3.

${ }^{173}$ Ibid, 911.
} 
Convention or English national law. ${ }^{174}$ It remains to be seen whether English courts will take a different approach to the enforceability of optional jurisdiction clauses under the Recast.

\section{E. Conclusion}

The above discussion highlights some issues yet to be resolved in the treatment of jurisdiction agreements, particularly relating to non-unique exclusive agreements and unilateral optional agreements. The principal justifications for the enforcement of the parties' choices of court are that this promotes certainty, predictability and efficiency; reduces the risk of multiple proceedings; and simplifies the resolution of jurisdictional disputes. As we have shown, non-unique exclusive agreements and unilateral optional agreements may frustrate rather than promote the achievement of these objectives.

These types of agreements are problematic for a number of reasons, as we have explained. There is a lack of clarity and consistency as to whether non-unique agreements come within the definition of exclusive agreements. They clearly do not do so under the Hague Convention but some non-unique agreements may fall within the definitions of exclusivity under the Recast and at common law. Assuming that a non-unique agreement might be recognised as exclusive, it is uncertain how parallel proceedings brought in reliance on that agreement ought to be resolved, and the best solution to this problem that has so far been proposed is the lis pendens rule. This undermines one of the most significant benefits of jurisdiction agreements in reducing disputes about forum.

\footnotetext{
${ }^{174}$ Law Debenture was the only one of these cases in which the governing law is not clear. However, the approach taken by Mann J was consistent with the English approach to construction of dispute resolution clauses.
} 
The effect of unilateral optional agreements is also unclear and uncertain. France's highest court has not enforced them, viewing their uncertainty and different impact on the parties as incompatible with the Regulation and Lugano Convention. To the extent that a unilateral optional agreement leaves the designation of jurisdiction to the discretion of one party, and is uncertain in that it would not enable a well-informed party reasonably to foresee the courts before which it would be required to participate in litigation, the reasoning of the Cour de cassation is cogent. These features are not regarded as problematic by English courts, which regard unilateral optional clauses as enforceable. The divergent treatment of such clauses means that their enforceability depends on the fora in which principal and enforcement proceedings are brought. This may be exploited by well-advised litigants, completely undermining the benefits and purpose of jurisdiction agreements.

These observations suggest that agreements which differ from the standard model of a uniquely exclusive jurisdiction agreement should be used with caution in practice. They also indicate the need for further research into the legitimacy, effectiveness, and practical operation of such provisions. 